\title{
Prevalence of Tumor necrosis factor alpha inducing protein (tipa) gene of Helicobacter pylori and its association with Upper Gastrointestinal Diseases in India
}

\section{Shweta Mahant}

Amity University

Shubham Mehra

Amity University

Ayushi Chhawchharia

Amity University

Bipul Chandra Karmakar

National Institute of Cholera and Enteric Diseases

Sangita Paul

National Institute of Cholera and Enteric Diseases

Asish Kumar Mukhopadhyay

National Institute of Cholera and Enteric Diseases

\section{Sudeep Bose}

Amity University

Kunal Das

Manipal Hospitals

Rajashree Das ( $\sim$ rajashreepatra79@yahoo.co.in )

Amity University

Research article

Keywords: Helicobacter pylori, Tumor necrosis factor alpha inducing protein, Gastric Cancer, Gastroduodenal diseases

Posted Date: October 21st, 2020

DOl: https://doi.org/10.21203/rs.3.rs-38351/v2

License: (9) This work is licensed under a Creative Commons Attribution 4.0 International License. Read Full License 
Version of Record: A version of this preprint was published at 3 Biotech on April 30th, 2021. See the published version at https://doi.org/10.1007/s13205-021-02804-w. 


\section{Abstract}

Background: Helicobacter pylori (H. pylori) is known to cause several gastro-duodenal diseases including chronic Gastritis, Peptic Ulcer disease and Gastric Cancer. Virulent genes of H. pylorilike cagA, vacA are known to be responsible for the disease pathogenesis. But these virulence genes are not always found to be associated with disease outcome in all populations around the world. Relationship of H. pylori with Gastro Esophageal Reflux Diseases is controversial and uncertain. Tumor necrosis factor alpha inducing protein tipa is a new discovered virulent gene of $\mathrm{H}$. pylori and is an inducer of certain cytokines and chemokines that are responsible for causing stomach cancer. Therefore, we conducted a study which aims to find the prevalence of tipa gene in the Indian population and its association with $H$. pylori related upper gastrointestinal diseases.

Results: 267 clinical H. pylori isolates are included in our study for finding the prevalence of tipa gene and its association with cagA and vacA gene using PCR assay. The current study shows the prevalence rate of tipa gene in the Indian population to be $59.9 \%$. Our study has found a significant association $(p<0.05)$ of tipa gene with Non Ulcer Dyspepsia (NUD) and also an association of $\operatorname{cag} A$ and $\operatorname{vac} A \operatorname{sim} 1$ with Gastritis and Duodenal Ulcer.

Conclusion: Our study demonstrates for the first time the presence of tipa as virulent factor of $H$. pylori strain in Indian population isolated from patients suffering from upper gastrointestinal diseases. Further, tipa is significantly associated with NUD but not with other upper gastrointestinal diseases in India.

\section{Background}

Helicobacter pylori (H. pylori) is a Gram negative microaerophilic bacterium that chronically colonizes the gastric epithelium of more than half of the world population and plays an important role in the pathogenesis of several gastro-duodenal diseases such as chronic Gastritis, Peptic Ulcer Disease (PUD) and Gastric Cancer [1]. In India about $53.4 \%$ to $73.5 \%$ of the population is infected by $H$. pylori [2]. There is a wide geographical variation in both $H$. pylori related gastro-duodenal diseases as well as distribution of its virulent genes. The prevalence of Gastric Cancer is high in South India as compared to North India while the Eastern and the Northern regions of India have high rates of Duodenal Ulcer (DU) [3]. Role of various virulence factors of $H$. pylori, such as cytotoxin-associated gene Pathogenicity Island (cag PAl), cagA, vacuolating cytotoxin $A(\operatorname{vacA})$, and urease have been studied extensively in gastro-duodenal diseases in India and other parts of the world [4-6]. In East-Asian countries most of the H. pylori strains are cagA-positive, while $20-40 \%$ of isolates from Europe and Africa are cagA-negative strains. It is shown that patients infected by cagA-positive H. pylori have a higher risk of developing PUD or Gastric Cancer compared to those infected with their cagA negative counterparts. However, in East Asia, most strains of H. pylori have the cagA gene irrespective of the disease [7]. In India there are wide geographical differences in the prevalence of $c a g A$ and vacA. About $90 \%$ strains from East India [8], 66.6\% H. pylori strains of North-East India [9] and whereas only $50 \%$ of the strains from North India are cagA positive (our unpublished data). Also about $80-90 \%$ of the strains from East India are vacA $1 \mathrm{~m} 1$ whereas $60.7 \%$ of the 
North East India are vacAs1m1 $[9,10]$. Therefore, as in the Indian population the strains with $\mathrm{s} 1 \mathrm{~m} 1$ are pre-dominant. Since there is wide variation in $\operatorname{cag} A$ and $v a c A$ prevalence rates in different geographies in India and also in different parts of the world, it demonstrates that the diseases are multi-factorial. Hence, there is a need to identify other virulent factors which may be responsible for disease causation.

Tumor necrosis factor alpha inducing protein (Tipa) of $H$. pylori is a carcinogenic factor that induces tumor promotion in vitro and in vivo [11-13]. In vitro study by Suganuma et al 2008 shows the binding of tipa to surface nuceolin on human Gastric Cancer cell line and that internalization of the tipa and nucleolin complex induces tumor progression and epithelial mesenchymal transition in human Gastric Cancer $[13,14]$. Tipa is a new NF-KB activating protein of $H$. pylori associated with strong induction of TNF-a in combination with RAS activation. When H. pylori infection occurs in the stomach epithelium in which Ras protein is activated or overexpressed, Tipa dimer is assumed to play a carcinogenic role leading to Gastric Cancer [15]. However, if $H$. pylori infection occurs in the stomach epithelium without activated Ras protein, Tipa dimer will probably not produce Gastric Cancer, but only inflammation (Gastritis and Gastric Ulcer). Although activated Ras protein is not often found in human stomach cancer, it is now possible to conceive a new regulatory mechanism of Ras protein with the let-7 microRNA [15]. Though there is a published sequence of one of the Indian strains of H. pylori (India 7 strain (NC_017372), (HPIN_03690) showing the presence of this gene, there are no studies on Tumor necrosis factor inducing protein (Tipa) from India. Tipa, which induces the expression of variety of proinflammatory cytokines including TNF and IL-1, is over-expressed in gastric mucosa exposed to $\mathrm{H}$. pylori [13]. Although, India constitutes around one-sixth of the world population, there are no studies on the prevalence of tipa in H. pylori related gastrointestinal diseases. This prompted us to study the prevalence of the tipa genes from $H$. pylori strains isolated from various parts of India and its association with $H$. pylori related gastrointestinal diseases.

\section{Results}

\section{Prevalence of tipa gene in the Indian population}

267 clinical H. pylori isolates are included in our study were isolated from - -Gastritis $(n=80)$, Duodenal Ulcer (DU) ( $n=77)$, Non Ulcer Dyspepsia (NUD) ( $n=51)$, Gastric Ulcer $(n=7)$, Gastro-Esophageal Reflux Disease (GERD) ( $n=32)$ and Controls $(n=20)$. The Male:Female (M:F) was 59:30 and mean age group was $43.03 \pm 16.19$.

The genotyping of tipa was done using primer as shown in Table 4 which gave an amplicon size of 168 bp (Figure 1). The prevalence rate of tipa gene was found to be $59.9 \%$ (160 out of 267 ) (95\% Cl: $54.36 \%$ to $100 \%)$ in the Indian population. However, $100 \%(27 / 27)$ of the $H$. pylori strains isolated from East India are tipa positive followed by $90 \%$ (9/10) in South India, 75.3\% (49/65) in North India and only $45.4 \%$ (75/165) in North-East India (Table 1).

\section{Genotypic status of $\operatorname{cag} A$ and vacA gene}


Multiplex PCR was done for detection of cagA and vacA gene in all H. pylori isolates. (Figure 2). The cagA gene was detected in $79.8 \%$ isolates $(213 / 267)(95 \% \mathrm{Cl}: 53.7 \%$ to $97.6 \%)$ and rest $20.3 \%$ isolates (54/267) showed absence of cagA gene which was further confirmed using empty site PCR (Table 1$)$. Region wise more than $90 \%$ of the H. pylori isolates are cagA positive in North East India $93.9 \%$ (155/165) and South India 90\% (9/10) followed by East India showing prevalence of 74\% (20/27). However surprisingly only $44.6 \%(29 / 65)$ of the North Indian strains are cagA positive (Table 1$)$.

The genotype of different vacA alleles examined in overall isolates were found to be $\mathrm{s} 1 \mathrm{~m} 1$ in $75.3 \%$ (201/267), s2 $\mathrm{m} 2$ in $16.8 \%(45 / 267)$ and $\mathrm{s} 1 \mathrm{~m} 2$ in $7.9 \%$ (21/267) isolates (Table 1). vacA s1 $\mathrm{m} 1$ allele is found to be positive in more than $90 \%$ of the $H$. pylori isolates from North East and South India. The $H$. pylori isolates from East India shows that 55.5\% (15/27) strains are s1 1 1, 18.5\% (5/27) are s1 $\mathrm{m} 2$ and only $25.9 \%$ (7/27) of the strains are s $2 m 2$. However, the strains from North India shows that $40 \%(26 / 65)$ are $\mathrm{s} 1 \mathrm{~m} 1,16.9 \%(11 / 65)$ are $\mathrm{s} 1 \mathrm{~m} 2$ while $43 \%(28 / 65)$ are s $2 \mathrm{~m} 2$ (Table 1$)$.

Table 1: Prevalence of tipa, cagA and vacA gene in H. pylori isolates from different regions of India.

\begin{tabular}{|c|c|c|c|c|c|c|c|c|}
\hline $\begin{array}{l}\text { Isolates } \\
\text { from } \\
\text { different } \\
\text { states }\end{array}$ & $\begin{array}{l}\text { Total no. } \\
\text { of } \\
\text { isolates }\end{array}$ & $\begin{array}{l}\text { tipa } \\
\text { positive } \\
\text { isolates } \\
(\%)\end{array}$ & $\begin{array}{l}\text { tipa } \\
\text { negative } \\
\text { isolates } \\
(\%)\end{array}$ & $\begin{array}{l}\text { cagA } \\
\text { positive } \\
\text { isolates } \\
(\%)\end{array}$ & $\begin{array}{l}\operatorname{cag} A \\
\text { negative } \\
\text { isolates } \\
(\%)\end{array}$ & $\begin{array}{l}\text { vacA } \\
\text { s1m1 } \\
(\%)\end{array}$ & $\begin{array}{l}\operatorname{vacA} \\
s 2 \mathrm{~m} 2 \\
(\%)\end{array}$ & $\begin{array}{l}\operatorname{vacA} \\
\text { s1m2 } \\
(\%)\end{array}$ \\
\hline $\begin{array}{l}\text { North East } \\
\text { India }\end{array}$ & 165 & $75(45.4)$ & $\begin{array}{l}90 \\
(54.5)\end{array}$ & $\begin{array}{l}155 \\
(93.9)\end{array}$ & $\begin{array}{l}10 \\
(6.1)\end{array}$ & $\begin{array}{l}151 \\
(91.5)\end{array}$ & $\begin{array}{l}10 \\
(6.06)\end{array}$ & $\begin{array}{l}4 \\
(2.42)\end{array}$ \\
\hline North India & 65 & $49(75.3)$ & $\begin{array}{l}16 \\
(24.6)\end{array}$ & $\begin{array}{l}29 \\
(44.6)\end{array}$ & $\begin{array}{l}36 \\
(55.4)\end{array}$ & $\begin{array}{l}26 \\
(40)\end{array}$ & $\begin{array}{l}28 \\
(43)\end{array}$ & $\begin{array}{l}11 \\
(16.9)\end{array}$ \\
\hline South India & 10 & $\begin{array}{l}9 \\
(90)\end{array}$ & $\begin{array}{l}1 \\
(10)\end{array}$ & $\begin{array}{l}9 \\
(90)\end{array}$ & $\begin{array}{l}1 \\
(10)\end{array}$ & $\begin{array}{l}9 \\
(90)\end{array}$ & $\begin{array}{l}0 \\
(0)\end{array}$ & $\begin{array}{l}1 \\
(10)\end{array}$ \\
\hline East India & 27 & $\begin{array}{l}27 \\
(100)\end{array}$ & $\begin{array}{l}0 \\
(0)\end{array}$ & $\begin{array}{l}20 \\
(74)\end{array}$ & $\begin{array}{l}7 \\
(26)\end{array}$ & $\begin{array}{l}15 \\
(55.5)\end{array}$ & $\begin{array}{l}7 \\
(25.9)\end{array}$ & $\begin{array}{l}5 \\
(18.51)\end{array}$ \\
\hline Total & 267 & $\begin{array}{l}160 \\
(59.9)\end{array}$ & $\begin{array}{l}107 \\
(40.1)\end{array}$ & $\begin{array}{l}213 \\
(79.8)\end{array}$ & $\begin{array}{l}54 \\
(20.3)\end{array}$ & $\begin{array}{l}201 \\
(75.3)\end{array}$ & $\begin{array}{l}45 \\
(16.8)\end{array}$ & $\begin{array}{l}21 \\
(7.9)\end{array}$ \\
\hline
\end{tabular}

\section{Association of tipa, cagA, vacA with different disease outcomes}

Table 2 shows association of tipa, cagA and vacA with different disease outcomes. Our study shows the presence of tipa gene in $\mathrm{H}$. pylori isolated from patients suffering from various upper gastrointestinal diseases - 41.3\% Gastritis (33/80), 84.38\% Non Ulcer Dyspepsia (43/51), 58.4\% Duodenal Ulcer (45/77), 
42.9\% Gastric Ulcer (3/7), 75\% GERD (24/32). The association of tipa gene was found significant only in Non Ulcer Dyspepsia (NUD) with respect to the controls $(p<0.05)$ (Table 2). Significant association of cagA virulent gene was found in Duodenal Ulcer $(p<0.01)$ and Gastritis $(p<0.001)$. vacAs $1 \mathrm{~m} 1$ allele was also found to be significantly associated with Duodenal Ulcer $(p<0.05)$ and Gastritis $(p<0.05)$.

Table 2: Detection and distribution of $H$. pylori and virulent genes in patients with various gastrointestinal disease outcomes.

\begin{tabular}{|c|c|c|c|c|c|c|c|}
\hline & $\begin{array}{l}\text { Control } \\
(\%) \\
n=20 \\
(7.5)\end{array}$ & $\begin{array}{l}\text { Gastritis } \\
(\%) \\
n=80 \\
(29.9)\end{array}$ & $\begin{array}{l}\text { GERD (\%) } \\
n=32 \\
(12)\end{array}$ & $\begin{array}{l}\text { NUD } \\
(\%) \\
\mathrm{n}=51 \\
(19.1)\end{array}$ & $\begin{array}{l}\text { DU (\%) } \\
n=77 \\
(28.8)\end{array}$ & $\begin{array}{l}\text { Gastric } \\
\text { Ulcer } \\
(\%) \\
\mathrm{n}=7 \\
(2.6)\end{array}$ & $\begin{array}{l}\text { Total } \\
(\%) \\
\\
\mathrm{n}= \\
267 \\
(100)\end{array}$ \\
\hline $\begin{array}{l}\operatorname{cag} A \\
\text { positive }\end{array}$ & $13(65)$ & $\begin{array}{l}74(92.5)^{*} \\
\left({ }^{*}=0.001\right)\end{array}$ & $16(50)$ & $\begin{array}{l}37 \\
(72.5)\end{array}$ & $\begin{array}{l}68(88.3) \\
*(*= \\
0.01)\end{array}$ & $5(71.4)$ & $\begin{array}{l}213 \\
(79.7)\end{array}$ \\
\hline $\begin{array}{l}\text { cagA } \\
\text { negative }\end{array}$ & 7 (35) & $6(7.5)$ & $\begin{array}{l}16 \\
(50)\end{array}$ & $\begin{array}{l}14 \\
(27.5)\end{array}$ & 9 (11.7) & $2(28.6)$ & $\begin{array}{l}54 \\
(20.3)\end{array}$ \\
\hline $\begin{array}{l}\text { tipa } \\
\text { positive }\end{array}$ & $12(60)$ & $33(41.3)$ & $24(75)$ & $\begin{array}{l}43 \\
(84.3) * \\
(*=0.02)\end{array}$ & $45(58.4)$ & $3(42.9)$ & $\begin{array}{l}160 \\
(59.9)\end{array}$ \\
\hline $\begin{array}{l}\text { tipa } \\
\text { negative }\end{array}$ & $8(40)$ & $47(58.8)$ & $8(25)$ & $8(15.7)$ & $32(41.6)$ & $4(57.1)$ & $\begin{array}{l}107 \\
(40.1)\end{array}$ \\
\hline vacAs1m1 & $12(60)$ & $\begin{array}{l}74(92.5) *(*= \\
0.00)\end{array}$ & $14(43.8)$ & $\begin{array}{l}31 \\
(60.8)\end{array}$ & $\begin{array}{l}65(84.4) \\
*(*= \\
0.05)\end{array}$ & $5(71.4)$ & $\begin{array}{l}201 \\
(75.2)\end{array}$ \\
\hline $\operatorname{vac} A s 2 \mathrm{~m} 2$ & $4(20)$ & $6(7.5)$ & $14(43.8)$ & $\begin{array}{l}12 \\
(23.5)\end{array}$ & $7(9.1)$ & $2(28.6)$ & $\begin{array}{l}45 \\
(16.9)\end{array}$ \\
\hline vacAs1m2 & $4(20)$ & $0(0)$ & $4(12.5)$ & 8 (15.7) & $5(6.5)$ & $0(0)$ & $\begin{array}{l}21 \\
(7.9)\end{array}$ \\
\hline
\end{tabular}

${ }^{*} \mathrm{p}<0.05$

\section{Association of tipa with cagA and vacA gene}

In our study we found $56.8 \%(121 / 213)$ cagA positive and $72.2 \%(39 / 54)$ cagA negative showed presence of tipa gene but the association was found to be not significant (Table 3). We found that $95.2 \%$ of $v a c A s 1 \mathrm{~m} 2$ also shows the presence of tipa and the association is found to be significant $(p<0.05)$. 
$71.1 \%$ of vacAs $2 \mathrm{~m} 2$ and $53.7 \%$ of vacAs $1 \mathrm{~m} 1$ shows the presence of tipa but the association was not significant.

Table 3: Association of vacA, cagA and tipa in H. pylori strains

\begin{tabular}{|lllllll|}
\hline & $\begin{array}{l}\text { Total H.pylori } \\
\text { isolates }(\%) \\
\mathrm{n}=267\end{array}$ & $\begin{array}{l}\text { cagA } \\
\text { positive } \\
(\%)\end{array}$ & $\begin{array}{l}\text { cagA } \\
\text { negative } \\
(\%)\end{array}$ & $\begin{array}{l}\text { vacAs1m1 } \\
(\%)\end{array}$ & $\begin{array}{l}\text { vacAs2m2 } \\
(\%)\end{array}$ & $\begin{array}{l}\text { vacAs1m2 } \\
(\%)\end{array}$ \\
\hline $\begin{array}{l}\text { tipa } \\
\text { Positive }\end{array}$ & $160(59.9)$ & $121(56.8)$ & $39(72.2)$ & $108(53.7)$ & $32(71.1)$ & $\begin{array}{l}20(95.2) * \\
\text { ** }\end{array}$ \\
$\begin{array}{l}\text { tipa } \\
\text { negative }\end{array}$ & $107(40.1)$ & $92(43.1)$ & $15(27.7)$ & $93(46.2)$ & $13(28.9)$ & $1(4.7)$ \\
\hline
\end{tabular}

*p $<0.05$

\section{Discussion}

There are several studies which have shown, that the incidence and / or severity of gastrointestinal diseases related to $H$. pylori may vary geographically [16]. Further, there are several reports for the presence of different strains of $H$. pylori with different degree of virulence indicating variation in the distribution of different virulent genes of $H$. pylori in different populations [17-19]. Several Indian studies show that $\operatorname{cag} A$ gene was found at a high frequency of $86 \%$ of the $H$. pylori strains and this virulence marker was found at almost equal frequencies in strains from DU patients $(90.6 \%)$ and NUD patients $(82 \%)$, indicating that the prevalence of the cagA gene cannot be considered as a key virulence marker for determination of the clinical status of the host $[10,20]$. This is very similar to the results in our present study, where we found the prevalence rate of $79.8 \%$ for cag $A$ positivity among $H$. pylori related gastrointestinal diseases. We found large geographical differences in the prevalence rates in different parts of India. We found that the prevalence of cagA in North India, South India, North-East India were $44.6 \%, 90 \%$ and $93.9 \%$ respectively. cagA was significantly associated $(p<0.05)$ with Gastritis and DU, where its prevalence was $92.5 \%$ and $88.3 \%$ respectively compared to prevalence rate of $65 \%(13 / 20)$ among controls. On the other hand, the prevalence of cagA gene among GERD, NUD and Gastric Ulcer were $50 \%, 72.5 \%$ and $71.4 \%$ respectively but was not significant. Our results are in line with the findings and observations of other studies from India which show a high cagA prevalence among DU and Gastritis patients. Prevalence was also high among NUD patients but they did not reach significance. The prevalence of $\operatorname{cag} A$ phenotype was also lower in patients with GERD as has been the observation of other studies as well [21].

We also found the overall prevalence rate of $75.2 \%$ for the vacAs $1 \mathrm{~m} 1$ allele was highest followed by vacAs $2 \mathrm{~m} 2(16.9 \%)$ and vacAs $1 \mathrm{~m} 2(7.9 \%)$. This data is in accordance to previous studies having about $70 \%$ s $1 \mathrm{~m} 1$ allele in Indian $H$. pylori isolates [10]. We found significant association $(p<0.05)$ of the 
virulent allele s1 $1 \mathrm{~m} 1$ with Gastritis and Duodenal Ulcer but not with others viz. GERD, DU and Gastric Ulcer. Our present observations are in line with the other studies from India stating higher prevalence of virulent genes in PUD [20]. Saxena et al reported a high occurrence of cagA in H. pylori isolates; 80 per cent in GC, $83.3 \%$ in PUD $76.7 \%$ in NUD. Although there is geographical variation in the prevalence of vacAs $1 \mathrm{~m} 1$ with $91.5 \%$ in North East India, 90\% in South India, 74\% in East India. In North India, the prevalence of $\mathrm{s} 1 \mathrm{~m} 1$ is $40 \%$ where as $43 \%$ is $\mathrm{s} 2 \mathrm{~m} 2$ which is similar to reports from Kauser et al 2005 from Ladakh, India where they found that $60 \%$ of the strains have s2 genotype [22].

This study shows the prevalence of tipa gene among the Indian H. pylori strains and its association with virulent genes $\operatorname{cag} A$, vacA gene in various gastrointestinal diseases. Our study shows that the overall prevalence of tipa, among the Indian $H$. pylori isolates is $59.9 \%$. NUD has been significantly associated with tipa with a prevalence rate of $86.3 \%$ compared to the prevalence of $60 \%$ among controls. The prevalence rate were similar to NUD (86.3\%) and GERD while the prevalence rates were much lower in Gastritis (41.3\%), DU (57.1\%) and Gastric Ulcer (42.9\%). The highest prevalence rate of tipa gene was found in $95.6 \%(22 / 23)$ vacAs $1 \mathrm{~m} 2$ positive $H$. pylori strains indicating a strong correlation between them. Another study has also reported increased mucosal IL-18 mRNA expression in vacAs $1 \mathrm{~m} 2$ allele causing increase in the risk of gastro-duodenal disease although no significance was found [23]. It has been found that Gastric Cancer patients infected with tipa positive strains of H. pylori produce significantly higher amounts of TNF- $a$ than patients with chronic Gastritis and that TNF- $a$ induced inflammatory response plays a significant role in the development of Gastritis and Gastric Cancer associated with $H$. pylori infection [24]. The pathogenesis of H.pylori associated with certain diseases such as gastritis and PUD can also be triggered by Immune system responses. Regulatory $T$ (Treg) cells which are responsible for H.pylori related inflammation and tenacity of bacteria may trigger such events [25]. Th17 cell count and the expression level of IL-8 and IL-17A were also observed to be significantly higher in PUD infected patients than patients with gastritis [26]. T-bet ${ }^{+}$cells and INF-y expression also have similar response as of Th17 cells. Interestingly, the number of T-bet ${ }^{+}$cells was positively associated with Th17 cell counts whereas there is an inverse association with cell count of Treg cells but all of them leads to increase in bacterial density [27].

Our study also demonstrates the significant association of tipa gene with Non Ulcer Dyspepsia (NUD). Non Ulcer Dyspepsia refers to heterogeneous and broad range of chronic upper abdominal symptoms which are widely shared with different gastrointestinal disorders. Therefore, NUD is generally diagnosed when other frequent gastrointestinal diseases are excluded, and upper endoscopy ruled out macroscopic lesions - i.e., Gastritis or Peptic ulcer. Such a condition is frequently encountered in clinical practice, its prevalence being close to $20 \%-30 \%$ in the general population and probably predates the occurrence of Gastritis and PUD. To date, no conclusive data have been reported on the role of $H$. pylori infection on these dysfunctions. A Cochrane Meta-analysis of 17 trials with 3,566 patients showed that there was a $10 \%$ (95\% Cl: 6-14) relative risk reduction of dyspepsia following $H$. pylori eradication as compared to placebo, with a NNT of 14 (95\% Cl: 10-25). H. pylori infection may cause dyspeptic symptoms in NUD through other mechanisms such as: (1) alterations of gastric acid secretion; (2) persistent and active 
inflammation of gastric mucosa; and (3) post-infective changes in gastroduodenal mucosa. Our study raises a possibility of tipa being the link between $H$. pylori and NUD. This merits a further larger studies to comprehensively understand this possibility [28].In summary, our results revealed the prevalence rate of tipa gene is $59.9 \%$ ( 160 out of 267 ) among the Indian population. There is a highly significant association between virulent gene $\operatorname{cag} A$ and $\operatorname{vacAs} 1 \mathrm{~m} 1$ alleles with Duodenal Ulcer and Gastritis. We found a significant association of tipa gene with Non Ulcer Dyspepsia (NUD). Limitation of this study is detailed demographics like alcohol, smoking, dietary habits, Weight, Height was not available for all samples. Also the sample size of the study is limited.

\section{Conclusion}

The present study concludes for the first time that the Indian population has $59.9 \%$ prevalence rate of tipa gene. Our study also shows that there is an association of tipa with vacAs $1 \mathrm{~m} 1$ and $\operatorname{cag} A$ gene with Duodenal Ulcer and tipa gene with Non Ulcer Dyspepsia (NUD) disease.

\section{Abbreviation}

Non Ulcer Dyspepsia (NUD)

Helicobacter pylori (H. pylori)

Peptic Ulcer Disease (PUD)

Duodenal Ulcer (DU)

vacuolating cytotoxin $A(\operatorname{vac} A)$

cytotoxin-associated gene Pathogenicity Island (cag PAI)

cytotoxin-associated gene A (cagA)

Tumor necrosis factor alpha inducing protein (Tipa)

Gastro-Esophageal Reflux Disease (GERD)

\section{Methods}

\section{Collection of $H$. pylori specimen}

A total of $267 \mathrm{H}$. pylori positive isolates across different parts of India were included in the study-North India $(n=65)$, South India $(n=10)$, East India $(n=27)$ and North-East India $(n=165)$. Three gastric biopsy samples were collected from patients suffering from various $\mathrm{Gl}$ symptoms as per the inclusion criteria and Exclusion criteria. Inclusion criteria includes :- age 18- 80 years, consent for upper gastrointestinal endoscopy, symptoms suggestive of $\underline{H}$. pylori related gastro duodenal disease. Exclusion criteria were: 
use of antibiotics, antihistamines, and proton pump inhibitors 3 months prior to the study. The biopsies were taken from gastric antrum, around $2-4 \mathrm{~cm}$ from the pylorus. Two biopsies were taken for isolation of $H$. pylori and one for Rapid urease test. The presence of $H$. pylori was confirmed by culture, Rapid urease Test and genotyping.The $H$. pylori strains included in our study were isolated from patients suffering from various upper gastro intestinal tract diseases $(n=247)$ and controls $(n=20)$. The control group consisted of subjects who underwent upper $\mathrm{GI}$ endoscopy due to reasons other than $H$. pylori related gastro duodenal diseases e.g. Chronic Diarrhoea, Chronic Liver Disease (CLD) and underwent endoscopy as a part of standard treatment protocol. The purpose of including the control group is to compare the prevalence of Tipa inducing protein gene and other $H$. pylori virulent genes in upper gastro intestinal diseases (Diseased group) to controls (Non H. pylori related Diseased group

\section{Culturing of $H$. pylori and DNA extraction}

Brucella broth containing the biopsy samples were vortexed in laboratory for 2 min and $200 \mu$ l of the mixture was streaked onto on brain heart infusion agar plates with charcoal (BHIA; Becton Dickinson, Sparks, MD, USA) which was supplemented with $5 \%$ Horse Serum; $0.4 \%$ IsovitaleX (Becton Dickinson, Sparks, MD, USA) and antibiotics such as Amphotericin B $(8 \mu \mathrm{g} / \mathrm{ml})$, Trimethoprim $(5 \mu \mathrm{g} / \mathrm{ml})$ and Vancomycin $(6 \mu \mathrm{g} / \mathrm{ml})$ and incubated under microaerophilic condition $\left(5 \% \mathrm{O}_{2} ; 10 \% \mathrm{CO}_{2} ; 85 \% \mathrm{~N}_{2}\right)$ in a double gas incubator (Heracell $150 \mathrm{i}$ ) at $37^{\circ} \mathrm{C}$. H. pylori were identified on the basis of their typical water droplet like morphology and urease, oxidase and catalase test result. The genomic DNA was extracted using standard protocol of CTAB [29] method with phenol/chloroform and isopropanol precipitation as described elsewhere as well as kit based method (QIAamp DNA Mini Kit) as per the manufacturer protocol and was stored at $-20^{\circ} \mathrm{C}$ at Amity University, Noida and NICED, Kolkata.

\section{Molecular characterization of genotypic status by PCR Amplification}

Genotyping of urease gene was done to confirm the presence of $H$. pylori by using the primer listed in Table 4 [30]. 267 H. pylori isolates included in our study were further amplified for cagA and vacA gene by multiplex PCR assay using 2.5 pmol of primers VAG-F and VAG-R, 25 pmol of primers VAI-F and VAI-R, $10 \mathrm{pmol}$ of primers cag $5 \mathrm{c}-\mathrm{F}$ and cag3c-R as shown in Table 4 [31].

Genotyping of tipa gene was carried out using simplex PCR (Table 4). The PCR was performed with the final volume of $20 \mu$ l holding $10 \mathrm{ng}$ of bacterial genomic DNA, $20 \mathrm{pmol}$ of each primer, $0.25 \mathrm{mM}$ of each dNTPs (Bangalore Genei), $1 \mathrm{U}$ of Taq DNA polymerase (Bangalore Genei ) in standard PCR buffer (Bangalore Genei) containing $1.5 \mathrm{mM} \mathrm{MgCl}_{2}$ and were amplified according to cycling conditions: 35 cycles at $94^{\circ} \mathrm{C}$ for 1 minute, $60^{\circ} \mathrm{C}$ for 1 minute and $72^{\circ} \mathrm{C}$ for 1 minute with final extension of 10 min at $72^{\circ}$ $\mathrm{C}$ in Eppendorf (Vapo- protect). Amplified products of multiplex and simplex PCR were then analyzed by using $2 \%$ and $1 \%$ agarose gel respectively in 1 X TAE buffer containing $0.05 \% \mu \mathrm{g} / \mathrm{ml} \mathrm{EtBr}$ followed by screening running under UV trans-illuminator (Tarsons).

\section{Statistical Analysis:}


Fisher exact test or chi square was used to calculate the $P$ value which was defined as statistically significant with $P$ value $<0.05$ and also the $95 \%$ confidence interval $(\mathrm{Cl})$ was calculated using SPSS V.18.0 software for Windows (SPSS Inc., Chicago, IL, USA). Microsoft word and Excel have been used to generate graphs, tables .

Table 4: Primers used for the genotyping of $H$. pylori strains.

\begin{tabular}{|c|c|c|c|c|}
\hline Genes & Primer & Nucleotide sequence ( $5^{\prime}$ to $3^{\prime}$ ) & $\begin{array}{l}\text { Amplicon size in } \\
\text { bp }\end{array}$ & References \\
\hline \multirow[t]{2}{*}{ ureaseB } & ureB-F & CGTCCGGCAATAGCTGCCATAGT & \multirow[t]{2}{*}{428} & \multirow[t]{2}{*}{ [30] } \\
\hline & ureB-R & GTAGGTCCTGCTACTGAAGCCTTA & & \\
\hline \multirow[t]{2}{*}{$\begin{array}{l}\operatorname{cag} A\left(5^{\prime}\right. \\
\text { end })\end{array}$} & $\begin{array}{l}\text { cag5c- } \\
\mathrm{F}\end{array}$ & GTTGATAACGCTGTCGCTTCA & \multirow[t]{2}{*}{350} & \multirow[t]{2}{*}{ [31] } \\
\hline & $\begin{array}{l}\text { cag3c- } \\
\mathrm{R}\end{array}$ & GGGTTGTATGATATTTTCCATAA & & \\
\hline \multirow[t]{2}{*}{$\operatorname{vac} A \mathrm{~s} 1 / \mathrm{s} 2$} & VAI-F & ATG GAA ATA CAA CAA ACA CAC & \multirow[t]{2}{*}{$s 1 ; 259 \mathrm{~s} 2 ; 286$} & \multirow[t]{2}{*}{ [31] } \\
\hline & VAI-R & CTG CTT GAA TGC GCC AAA C & & \\
\hline \multirow{2}{*}{$\begin{array}{l}\operatorname{vacA} \\
\mathrm{m} 1 / \mathrm{m} 2\end{array}$} & VAG-F & CAATCTGTCCAATCAAGCGAG & \multirow[t]{2}{*}{$\mathrm{m1;567} \mathrm{m2;} 642$} & \multirow[t]{2}{*}{ [31] } \\
\hline & VAG-R & GCGTCAAAATAATTCCAAGG & & \\
\hline \multirow[t]{2}{*}{ tip-a } & Tip-a-F & $\begin{array}{l}\text { GTT TAT CCA AAT GAC ACA GCC } \\
\text { CAT }\end{array}$ & \multirow[t]{2}{*}{168} & \multirow[t]{2}{*}{ This study } \\
\hline & Tip-a-R & $\begin{array}{l}\text { CAC CGC TTG ATT GTC TAA GGA } \\
\text { CAT }\end{array}$ & & \\
\hline
\end{tabular}

\section{Declarations}

Ethics approval and consent to participate: This study was approved by institutional ethical committee of Amity Institute of Biotechnology, Noida, U.P, dated 2-12-2015 and National Institute of Cholera and Enteric Diseases, Kolkata (A-1/2016-IEC, dated 22-12-2016). Written informed consent was taken.

Consent to Publish: Not Applicable

Availability of data and materials: The datasets used and/or analyzed during the current study are available from the corresponding author on reasonable request

Competing interests: The authors declare that they have no competing interests

Funding: This study has been funded by ICMR (5/13/16/2015/NCD-III) 
Acknowledgement: We thank Amity University for providing the infrastructure and support to carry out the work.

Authors' contributions: RD and SB have given the concept of association between Tip a and Gastric Cancer. RD and AKM have finalized the manuscript. SM, SP, BCK and AC have done the experiments. SM has analyzed the data and written the manuscript. AKM has provided the samples and revised the manuscript. KD has conceptualized the idea clinically and critically corrected the manuscript.

\section{References}

1. Thirumurthi S, Graham DY. Helicobacter pylori infection in India from a western perspective. The Indian journal of medical research. 2012 Oct;136(4):549.

2. Hooi JK, Lai WY, Ng WK, Suen MM, Underwood FE, Tanyingoh D, Malfertheiner P, Graham DY, Wong VW, Wu JC, Chan FK. Global prevalence of Helicobacter pylori infection: systematic review and metaanalysis. Gastroenterology. 2017 Aug 1;153(2):420-9.

3. Misra V, Misra SP, Singh MK, Singh P A, Dwivedi M. Preva- lence of H. pylori in patients with gastric cancer. Indian J Pathol Microbiol 2007; 50: 702-707.

4. Atherton JC, Cao P, Peek RM, Tummuru MK, Blaser MJ, Cover TL. Mosaicism in vacuolatingcytotoxin alleles of Helicobacter pylori association of specific vacA types with cytotoxin production and peptic ulceration. Journal of Biological Chemistry. 1995 Jul 28;270(30):17771-7.

5. Normark S, Nilsson C, Normark BH, Hornef MW. Persistent infection with Helicobacter pylori and the development of gastric cancer. Advances in cancer research. 2003 Jan 1;90:63-91.

6. Patel TN, Roy S, Ravi R. Gastric cancer and related epigenetic alterations. Ecancermedicalscience. $2017 ; 11$.

7. Shimoyama T, Fukuda S, Tanaka M, Mikami T, Saito Y, Munakata A. High prevalence of the CagApositive Helicobacter pylori strains in Japanese asymptomatic patients and gastric cancer patients. Scandinavian journal of gastroenterology. 1997 Jan 1;32(5):465-8.

8. Patra R, Chattopadhyay S, De R, Ghosh P, Ganguly M, Chowdhury A, Ramamurthy T, Nair GB, Mukhopadhyay AK. Multiple infection and microdiversity among Helicobacter pylori isolates in a single host in India. PloS one. 2012;7(8).

9. Sarma A, Saikia L, Bhuyan RK, Hussain E. Molecular identification and detection of virulent factors in Helicobacter pylori from gastric biopsy samples of patients attended at Assam Medical College and Hospital, Dibrugarh, Assam, India. Indian journal of medical microbiology. 2017 Oct 1;35(4):600.

10. Santanu Chattopadhyay, Simanti Datta, Abhijit Chowdhury, Sujit Chowdhury, Asish K. Mukhopadhyay, K. Rajendran,S. K. Bhattacharya, Douglas E. Berg, and G. Balakrish Nair. Virulence Genes in Helicobacter pylori Strains from West Bengal Residents with Overt H. pylori-Associated Disease and Healthy Volunteers journal of clinical microbiology, July 2002, p. 2622-2625 Vol. 40, No. 7 0095-1137/02/\$04.00 0 DOI: 10.1128/JCM.40.7.2622-2625.2002 
11. Suganuma M, Kurusu M, Okabe S, Sueoka N, Yoshida M, Wakatsuki Y, Fujiki H. Helicobacter pylori membrane protein 1: a new carcinogenic factor of Helicobacter pylor Cancer research. 2001 Sep $1 ; 61(17): 6356-9$.

12. Suganuma M, Kurusu M, Suzuki K, Nishizono A, Murakami K, Fujioka T, Fujiki H. New tumor necrosis factor-a-inducing protein released from Helicobacter pylori for gastric cancer progression. Journal of cancer research and clinical oncology. 2005 May 1;131(5):305-13.

13. Suganuma M, Yamaguchi K, Ono Y, Matsumoto H, Hayashi T, Ogawa T, Imai K, Kuzuhara T, Nishizono A, Fujiki H. TNF-a-inducing protein, a carcinogenic factor secreted from $\mathrm{H}$. pylori, enters gastric cancer cells. International journal of cancer. 2008 Jul 1;123(1):117-22.

14. Watanabe T, Takahashi A, Suzuki K, Kurusu-Kanno M, Yamaguchi K, Fujiki H, Suganuma M. Epithelial-mesenchymal transition in human gastric cancer cell lines induced by TNF-a-inducing protein of Helicobacter pylori. International journal of cancer. 2014 May 15;134(10):2373-82.

15. Johnson SM, Grosshans H, Shingara J, Byrom M, Jarvis R, Cheng A, Labourier E, Reinert KL, Brown D, Slack FJ. RAS is regulated by the let-7 microRNA family. Cell. 2005 Mar 11;120(5):635-47.

16. Torres LE, Melián K, Moreno A, Alonso J, Sabatier CA, Hernández M, Bermúdez L, Rodríguez BL. Prevalence of vacA, cagA and babA2 genes in Cuban Helicobacter pylori isolates. World journal of gastroenterology: WJG. 2009 Jan 14;15(2):204.

17. Blaser MJ, Perez-Perez GI, Kleanthous H, Cover TL, Peek RM, Chyou PH, Stemmermann GN, Nomura A. Infection with Helicobacter pylori strains possessing cagA is associated with an increased risk of developing adenocarcinoma of the stomach. Cancer research. 1995 May 15;55(10):2111-5.

18. Queiroz DM, Mendes EN, Carvalho AS, Rocha GA, Oliveira AM, Soares TF, Santos A, Cabrai MM, Nogueira AM. Factors Associated with Helicobactev pylori Infection by a cag A-Positive Strain in Children. The Journal of infectious diseases. 2000 Feb 1;181(2):626-30.

19. Yamaoka Y, Kato M, Asaka M. Geographic differences in gastric cancer incidence can be explained by differences between Helicobacter pylori strains. Internal medicine. 2008;47(12):1077-83.

20. Saxena A, Shukla S, Prasad KN, Ghoshal UC. Virulence attributes of Helicobacter pylori isolates \& their association with gastroduodenal disease. The Indian journal of medical research. 2011 May;133(5):514.

21. Vicari JJ, Peek RM, Falk GW, Goldblum JR, Easley KA, Schnell J, Perez-Perez GI, Halter SA, Rice TW, Blaser MJ, Richter JE. The seroprevalence of cagA-positive Helicobacter pylori strains in the spectrum of gastroesophageal reflux disease. Gastroenterology. 1998 Jul 1;115(1):50-7.

22. Kauser F, Hussain MA, Ahmed I, Ahmad N, Habeeb A, Khan AA, Ahmed N. Comparing genomes of Helicobacter pylori strains from the high-altitude desert of Ladakh, India. Journal of clinical microbiology. 2005 Apr 1;43(4):1538-45.

23. Bagheri N, Taghikhani A, Rahimian G, Salimzadeh L, Dehkordi FA, Zandi F, Chaleshtori MH, RafieianKopaei M, Shirzad H. Association between virulence factors of helicobacter pylori and gastric mucosal interleukin-18 mRNA expression in dyspeptic patients. Microbial pathogenesis. $2013 \mathrm{Dec}$ $1 ; 65: 7-13$.

Page $13 / 16$ 
24. Inoue K, Shiota S, Yamada K, Gotoh K, Suganuma M, Fujioka T, Ahmed K, Iha H, Nishizono A. Evaluation of a New Tumor Necrosis Factor-a-Inducing Membrane Protein of Helicobacter pylori as a Prophylactic Vaccine Antigen. Helicobacter. 2009 Oct;14(5):487-95.

25. Bagheri N, Azadegan-Dehkordi F, Rahimian G, Rafieian-Kopaei M, Shirzad H. Role of regulatory T-cells in different clinical expressions of Helicobacter pylori infection. Archives of Medical Research. 2016 May 1;47(4):245-54.

26. Bagheri N, Razavi A, Pourgheysari B, Azadegan-Dehkordi F, Rahimian G, Pirayesh A, Shafigh M, Rafieian-Kopaei M, Fereidani R, Tahmasbi K, Shirzad H. Up-regulated Th17 cell function is associated with increased peptic ulcer disease in Helicobacter pylori-infection. Infection, Genetics and Evolution. 2018 Jun 1;60:117-25.

27. Bagheri N, Shirzad H, Mirzaei Y, Nahid-Samiei M, Sanaei M, Rahimian G, Shafigh M, Zandi F, Tahmasbi K, Razavi A. T-bet+ cells polarization in patients infected with Helicobacter pylori increase the risk of peptic ulcer development. Archives of medical research. 2019 Apr 1;50(3):113-21.

28. Zullo A, Hassan C, De Francesco V, Repici A, Manta R, Tomao S, Annibale B, Vaira D. Helicobacter pylori and functional dyspepsia: an unsolved issue?. World Journal of Gastroenterology: WJG. 2014 Jul 21;20(27):8957.

29. Ausubel FM, Brent R, Kingston RE, Moore DD, Seidman JG, Smith JA, Struhl K. Current Protocols in Molecular Biology. New York: Greene pub- lishing and Wiley-Interscience; 1993.

30. Roth DE, Velapatiño B, Gilman RH, Su WW, Berg DE, Cabrera L, Garcia E, Gastrointestinal Physiology Working Group. A comparison of a string test-PCR assay and a stool antigen immunoassay (HpSA) for Helicobacter pylori screening in Peru. Transactions of the Royal Society of Tropical Medicine and Hygiene. 2001 Jul 1;95(4):398-9.

31. Chattopadhyay S, Patra R, Ramamurthy T, Chowdhury A, Santra A, Dhali GK, Bhattacharya SK, Berg DE, Nair GB, Mukhopadhyay AK. Multiplex PCR assay for rapid detection and genotyping of Helicobacter pylori directly from biopsy specimens. Journal of clinical microbiology. 2004 Jun 1;42(6):2821-4.

\section{Figures}




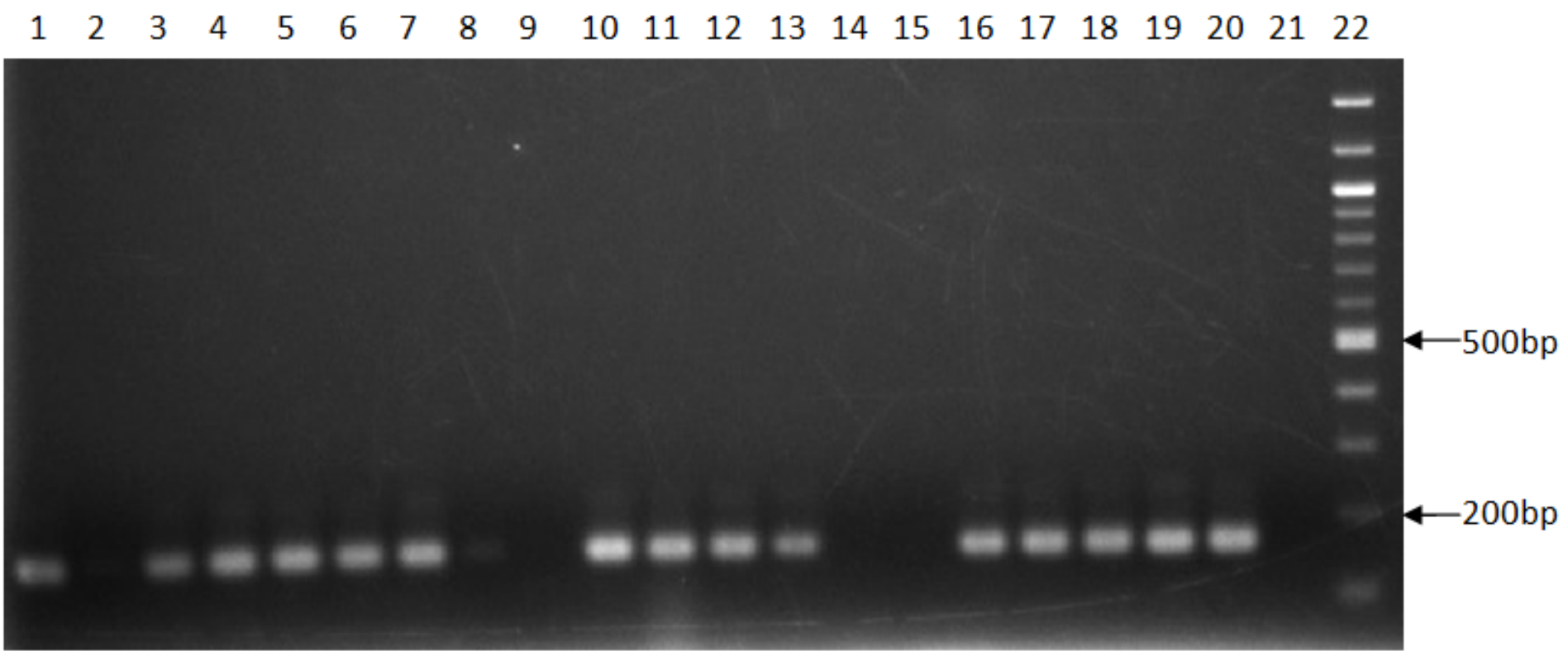

\section{Figure 1}

DNA amplification of tipa gene of 168bp from $\mathrm{H}$. pylori strains. Lane1- positive control, 26695; Lane 2-21 H. pylori clinical isolates and Lane 22- Marker (100bp).

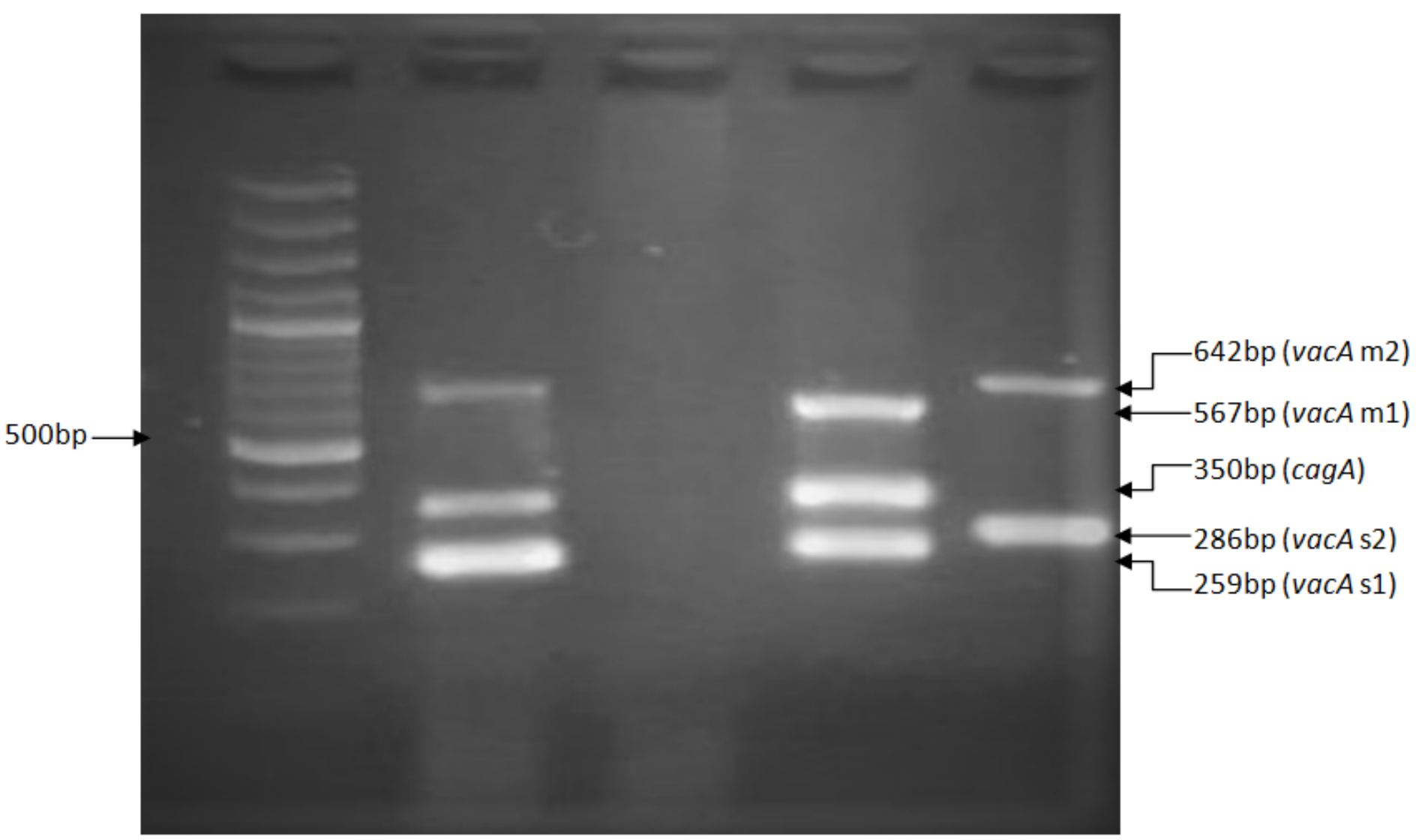

Figure 2 
Multiplex PCR of vacA s1/s2 and $\mathrm{m} 1 \mathrm{~m} 2$ and the cagA gene of $\mathrm{H}$. pylori strains. Lane 1, 100bp marker; lane 2 positive control, 26695, lane 3 negative control, lane $4 \mathrm{H}$. pylori clinical isolate cagA and vacA (s1m1), lane $5 \mathrm{H}$. pylori clinical isolate vacA (s2m2)

\section{Supplementary Files}

This is a list of supplementary files associated with this preprint. Click to download.

- Tablesuplementary.docx 